\title{
Thermodynamic analysis of synergistic coal gasification using blast furnace slag as heat carrier
}

Wenjun Duan, Qingbo Yu*, Huaqing Xie, Junxiang Liu, Kun Wang, Qin Qin, Zhicheng Han

School of Materials and Metallurgy, Northeastern University, No 11, Lane 3, Wenhua Road, He Ping District, Shenyang 110819, Liaoning, People's Republic of China.

*Corresponding author information:

Telephone/Fax: +86-024-83672216.

E-mail addresses: duanwenjn@163.com (W. J. Duan)

$$
\text { yuqb@smm.neu.edu.cn (Q. B. Yu) }
$$

Mailing address: P.O, Box345, Northeastern University, No11, Lane 3, Wenhua Road, Heping District, Shenyang, Liaoning, P. R. China. 


\section{Abstract}

In this paper, a thermodynamic analysis of the synergistic coal $/ \mathrm{CO}_{2} / \mathrm{H}_{2} \mathrm{O}$ gasification process with BFS (blast furnace slag) as heat carrier was performed using the Gibbs free energy minimization approach through Lagrange multiplier method. The effect of temperature, pressure and $\mathrm{C} / \mathrm{CO}_{2} / \mathrm{H}_{2} \mathrm{O}$ were investigated. Carbon, $\mathrm{CO}_{2}$ and $\mathrm{H}_{2} \mathrm{O}$ conversion, $\mathrm{H}_{2}$ and $\mathrm{CO}$ yield, and $\mathrm{H}_{2} / \mathrm{CO}$ ratio were used to characterize the synergistic gasification performance. The results showed that the atmospheric pressure was preferable for coal gasification and the increasing of temperature caused the increase in carbon conversion and syngas production. The optimal temperature of the synergistic gasification was $800-900{ }^{\circ} \mathrm{C}$. Not only did it ensure the coal gasification reaction completely, but also it recovered the BFS waste heat effectively. The results clearly showed that the addition of $\mathrm{H}_{2} \mathrm{O}$ and $\mathrm{CO}_{2}$ could lead to the reduction of the carbon residue and increase of the production of $\mathrm{H}_{2}$ and $\mathrm{CO}$, respectively. Meanwhile, it was beneficial to reduce the waste heat using to heating extra steam and enhance the coal/ $\mathrm{CO}_{2}$ gasification reaction rate by controlling the addition of $\mathrm{CO}_{2}$ and $\mathrm{H}_{2} \mathrm{O}$ reasonably. Moreover, the production syngas application was also investigated by changing the relative $\mathrm{CO}_{2} / \mathrm{C}$ ratio and $\mathrm{H}_{2} \mathrm{O} / \mathrm{C}$ ratio in the feed to modify the $\mathrm{H}_{2} / \mathrm{CO}$ ratio.

\section{Keywords:}

Blast furnace slag; Heat carrier; Thermodynamic analysis; Synergistic coal gasification; Syngas 


\section{Introduction}

Coal was the most abundant natural energy resource available all over the world [1]. An interesting way, more efficiently and cleanly, was intensely focusing. Gasification technology was a clean and highly efficient way of utilizing coal, and it had attracted a lot of researcher's interest in recent years [2-4].

Traditionally, coal gasification reaction was performed using $\mathrm{H}_{2} \mathrm{O}$ or $\mathrm{CO}_{2}$ as agent. The situation of energy consumption in the steam gasification of coal was studied by Kale et al [5-7]. Although a large amount of the hydrogen could be produced, a great deal of energy was needed in gasification process. Meanwhile, an inevitable drawback of this process was the $\mathrm{H}_{2} / \mathrm{CO}$ ratio higher than 3.0, which was higher than the needed ratio of the Fishcer-Tropsch process [8-9]. Many researchers had performed numerous investigations on gasification reaction with $\mathrm{CO}_{2}$ [10-13]. Although a large amount of $\mathrm{CO}_{2}$ could be absorbed in the gasification process, the gasification reactivity was found to depend on reaction temperature strongly. Therefore, focusing on the coal gasification in mixture of $\mathrm{CO}_{2}$ and $\mathrm{H}_{2} \mathrm{O}$ was necessary to improve the coal reactivity and decrease the energy consumption.

Kale et al [5] found that the synergistic gasification was an important process to enhance reactivity and reduce energy consumption. Roberts [14] presented the data of coal char gasification with mixture of $\mathrm{CO}_{2}$ and $\mathrm{H}_{2} \mathrm{O}$ at high pressure. The results showed that the reaction rate was not the sum of the two pure gas reaction rates. It was a complex combination of the two, which appears to be dependent on the relative of slow $\mathrm{C} / \mathrm{CO}_{2}$ reaction. The same conclusion was also obtained by Scala [15]. Wang 
[16] found that the reactivity of the $\mathrm{CO}_{2}$ and $\mathrm{H}_{2} \mathrm{O}$ gasification was better than that of any single agent and the synergistic effect was related to inherent minerals. Chen et al [17] found that the char gasification in mixture of $\mathrm{CO}_{2}$ and $\mathrm{H}_{2} \mathrm{O}$ was obviously lower than the sum of two rates of char independently reacting but higher than rate of each independent reaction. Guizani et al [18] indicated that $\mathrm{CO}_{2}$ and $\mathrm{H}_{2} \mathrm{O}$ reacted on the separate active sites when mixed atmospheres were used. $\mathrm{CO}_{2}$ did not favor or inhibit the coal/ $/ \mathrm{H}_{2} \mathrm{O}$ gasification reaction as it did not affect the coal structure. However, Bai et al [19] found that coal $/ \mathrm{H}_{2} \mathrm{O}$ gasification occurred the most rapidly at high temperature and its rate decreased with the volume fraction of $\mathrm{CO}_{2}$ increasing. Mostafavi [20] used the catalyst to enhance the gasification and water gas shift reaction rates and found that $\mathrm{CO}_{2}$ shifted the water gas shift reaction equilibrium forward, to increase $\mathrm{H}_{2}$ production. The same conclusion was also obtained by Sedghkerdar [21]. The gasification characteristics of coal with $\mathrm{H}_{2} \mathrm{O}$ and $\mathrm{CO}_{2}$ were also investigated at different pressures by $\mathrm{Li}$ [22]. The results showed that coal gasification mechanism in mixture of $\mathrm{CO}_{2}$ and $\mathrm{H}_{2} \mathrm{O}$ was connected with relative partial pressures of two reactant gases.

As is known to all, the gasification was an intense endothermic reaction. The large amount of syngas must be burned to generate heat for gasification reaction. Therefore, obtaining an appropriate heat source was necessary to guarantee the successful reaction and reduce the syngas consumption. BFS as a kind of by-product during ironmaking process, was exhausted at extremely high temperature and the energy carried by BFS was about $1700 \mathrm{MJ} / \mathrm{t}_{\text {slag }}[23,24]$. Luo [25-26] and Sun [27] used the 
biomass catalytic gasification reaction to recover the BFS waste heat and product syngas successfully. Meanwhile, Sun et al [28-29] also investigated the sewage sludge gasification using slags. Li [30-35] carried on the thorough research of utilizing coal gasification to produce the syngas with the proposed coal/ $\mathrm{CO}_{2} / \mathrm{slag}$ system. About $0.044 \mathrm{Mt} / \mathrm{Mt}_{\text {slag }}$ of $\mathrm{CO}$ was generated and the thermal-to-chemical conversion efficiency reached 35\%. On the basis of Li's study, Duan [36-39] investigated the coal $/ \mathrm{H}_{2} \mathrm{O}$ gasification process and analyzed conditions of syngas production and the BFS waste heat utilization of the integrated system.

It could be seen from above studies mentioned that the coal gasification could proceed smoothly in the presence of BFS, and the slag waste heat could be recovered effectively. However, the conditions of energy conversion and syngas production in the process of synergistic coal gasification with $\mathrm{CO}_{2}$ and $\mathrm{H}_{2} \mathrm{O}$ using $\mathrm{BFS}$ as heat carrier had not been fully studied. Therefore, the effect of temperature, pressure and inlet $\mathrm{C} / \mathrm{CO}_{2} / \mathrm{H}_{2} \mathrm{O}$ were fully investigated by thermodynamic analysis. The energy consumption and syngas production with various changes of $\mathrm{CO}_{2} / \mathrm{C}$ and $\mathrm{H}_{2} \mathrm{O} / \mathrm{C}$ were also studied. Moreover, the production syngas application was also investigated to make it more extensive in industry.

\section{Methodology}

\subsection{Equilibrium Modeling-Minimization of Gibbs free energy}

For a system in which many simultaneous reactions took place, the equilibrium calculations were performed through the Gibbs free energy minimization method 
[40-43]. The total Gibbs free energy of the system was defined as:

$G_{T, P}^{t}=\sum_{i=1}^{N} n_{i} \mu_{i}$

where $G_{T, P}^{t}$ was the total Gibbs free energy and $n_{i}$ was referred to each species. $\mu_{i}$ was the chemical potential of species $i$ that could be presented by:

$\mu_{i}=G_{f, i}^{0}+R T \ln \left(y_{i}\right)$

where, $G_{f, i}^{0}$ was the standard Gibbs free energy of formation species; $T$ was the temperature, $\mathrm{K} ; y_{i}$ was the mole fraction of gas species.

Finding an appropriate value of $n_{i}$ to make sure the total Gibbs free energy $G_{T, P}^{t}$ to reach minimum was a problem. In face of this problem, the method of the Lagrange multipliers was used to deal with this question by Koukkari P [44].

$\sum_{i=1}^{N} a_{i j} n_{i}=A_{j}, j=1,2,3, \ldots ., k$

where $a_{i j}$ was the number of atoms of the $j$ th element in each mole of the $i$ th species. $A_{j}$ was the total number of atoms of the $j$ th element in the system and $k$ was the total number of atoms. Next, the Lagrange multipliers $\left(\lambda_{k}\right)$ was introduced in Eq. (4).

$$
\sum_{k} \lambda_{k}\left(\sum_{i=1}^{N} a_{i j} n_{i}-A_{j}\right)=0
$$

The Eq. (5) could be formed by Eq. (1) and (4).

$$
L=G_{T, P}^{t}-\sum_{j=i}^{k} \lambda_{k}\left(\sum_{i=1}^{N} a_{i j} n_{i}-A_{j}\right)
$$

In order to find the value of the equilibrium composition, the Eq. (5) could be processed into Eq. (6).

$$
\left(\frac{\partial L}{\partial n_{i}}\right)=0
$$


Consequently, the value of each species present could be obtained by this method and the mass and energy keep balance when reaching the state of $d G_{T, P}^{t}$.

\subsection{Thermodynamic properties}

In order to ensure the value of the $G_{f, i}^{0}$, the values of the standard enthalpy of formation $\left(\Delta{\overline{H_{f, i}^{0}}}^{-}\right)$and standard entropy of formation $\left(\Delta S_{f, i}^{\overline{0}}\right)$ at temperature $T$ were needed.

$$
\Delta{\overline{G_{f, i}^{0}}}^{-}=\Delta \overline{H_{f, i}^{0}}-T \Delta S_{f, i}^{\overline{0}}
$$

The heat capacity, enthalpy and entropy at constant pressure for the standard state were formulated in terms of the polynomial equations as follows, and the all parameters needed in the process of calculations were provided by NASA technical memorandum 4513 [45].

$$
\begin{aligned}
& \frac{\overline{C_{P}}}{R}=a_{1}+a_{2} T+a_{3} T^{2}+a_{4} T^{3}+a_{5} T^{4} \\
& \frac{\overline{H_{f}^{0}}\left(T_{0}\right)}{R T_{0}}=a_{1}+\frac{a_{2} T_{0}}{2}+\frac{a_{3} T_{0}^{2}}{3}+\frac{a_{4} T_{0}^{3}}{4}+\frac{a_{5} T_{0}^{4}}{5} \\
& \frac{\overline{S_{f}^{0}}\left(T_{0}\right)}{R}=a_{1} \ln (T)+a_{2} T_{0}+\frac{a_{3} T_{0}^{2}}{2}+\frac{a_{4} T_{0}^{3}}{3}+\frac{a_{5} T_{0}^{4}}{4}+b_{2}
\end{aligned}
$$

2.3 Feedstock characterization and conversion process

The simulations were performed for gasification of China DT (Datong) bituminous coal using BFS as heat carrier, and compositions and properties of DT coal were shown in Table 1. In order to develop the model, under the premise of calculation results were not affected, the simplification of DT coal compositions was necessary [5, 46]. Based on Li et al [47] and Shabbar et al [41] results, 25 gas species in the production were considered, and it could be seen from previous study [36]. 
Table 1 The properties of DT bituminous coal

\begin{tabular}{cc|cc}
\hline \multicolumn{3}{c}{ The properties of DT bituminous coal } \\
\hline \multicolumn{1}{c|}{ Proximate Analysis (wt \%) } & \multicolumn{1}{c}{ Ultimate Analysis (wt \%) } \\
\hline Moisture & 9.05 & Carbon & 64.53 \\
Volatile matter & 38.38 & Hydrogen & 3.746 \\
Fixed carbon & 38.42 & Nitrogen & 0.956 \\
Ash & 14.15 & Sulfur & 0.561 \\
& & & 7.007 \\
\hline
\end{tabular}

Table 2 The list of BFS solid phase species

\begin{tabular}{lllll}
\hline The BFS solid phase species & & & \\
\hline $\mathrm{C}$ & $\mathrm{Al}_{2} \mathrm{O}_{3}$ & $\mathrm{CaO} \cdot \mathrm{MgO}$ & $\cdot 2 \mathrm{CaO} \cdot \mathrm{Al}_{2} \mathrm{O}_{3}$ & $\mathrm{CaO} \cdot \mathrm{MgO} \cdot \mathrm{SiO}_{2}$ \\
$\mathrm{CaO}$ & $\mathrm{Al}(\mathrm{OH})_{3}$ & $\mathrm{CaO} \cdot \mathrm{Al}_{2} \mathrm{O}_{3}$ & $2 \mathrm{CaO} \cdot \mathrm{SiO}_{2}$ & $\mathrm{CaO} \cdot \mathrm{MgO} \cdot 2 \mathrm{SiO}_{2}$ \\
$\mathrm{CaO}_{2}$ & $\mathrm{Fe}_{2} \mathrm{O}_{3}$ & $\mathrm{CaO} \cdot 2 \mathrm{Al}_{2} \mathrm{O}_{3}$ & $\cdot 2 \mathrm{FeO} \cdot \mathrm{SiO}_{2}$ & $\mathrm{CaO} \cdot \mathrm{Al}_{2} \mathrm{O}_{3} \cdot \mathrm{SiO}_{2}$ \\
$\mathrm{Ca}(\mathrm{OH})_{2}$ & $\mathrm{FeO}$ & $\mathrm{CaO} \cdot \mathrm{Fe}_{2} \mathrm{O}_{3}$ & $3 \mathrm{CaO} \cdot \mathrm{SiO}_{2}$ & $\mathrm{CaO} \cdot \mathrm{Al}_{2} \mathrm{O}_{3} \cdot 2 \mathrm{SiO}_{2}$ \\
$\mathrm{CaC}_{2}$ & $\mathrm{Fe}_{3} \mathrm{O}_{4}$ & $\mathrm{CaO} \cdot 6 \mathrm{Al}_{2} \mathrm{O}_{3}$ & $3 \mathrm{CaO} \cdot 2 \mathrm{SiO}_{2}$ & $2 \mathrm{CaO} \cdot \mathrm{MgO} \cdot 2 \mathrm{SiO}_{2}$ \\
$\mathrm{CaCO}_{3}$ & $\mathrm{Fe}_{0.947} \mathrm{O}$ & $\mathrm{MgO} \cdot \mathrm{Al}_{2} \mathrm{O}_{3}$ & $\cdot 3 \mathrm{CaO} \cdot \mathrm{Al}_{2} \mathrm{O}_{3}$ & $2 \mathrm{CaO} \cdot \mathrm{Al}_{2} \mathrm{O}_{3} \cdot 2 \mathrm{SiO}_{2}$ \\
$\mathrm{MgO}^{\mathrm{Fe}}$ & $\mathrm{Al}_{2} \mathrm{O}_{3} \cdot \mathrm{SiO}_{2}$ & $3 \mathrm{Al}_{2} \mathrm{O}_{3} \cdot 2 \mathrm{SiO}_{2}$ & $\cdot 3 \mathrm{CaO} \cdot \mathrm{MgO}_{2} \mathrm{SiO}_{2}$ \\
$\mathrm{MgCO}_{3}$ & $\mathrm{SiO}_{2}$ & $\mathrm{Al}_{2} \mathrm{O}_{3} \cdot 2 \mathrm{SiO}_{2}$ & $\cdot 12 \mathrm{CaO} \cdot 7 \mathrm{Al}_{2} \mathrm{O}_{3}$ & $\cdot 3 \mathrm{CaO} \cdot \mathrm{Al}_{2} \mathrm{O}_{3} \cdot 3 \mathrm{SiO}_{2}$ \\
\hline
\end{tabular}

Meanwhile, the BFS, from an iron and steel company was used in this numerical simulation as heat carrier, with the chemical compositions of $44.6 \% \mathrm{CaO}, 38.5 \% \mathrm{SiO}_{2}$, $8.1 \% \mathrm{Al}_{2} \mathrm{O}_{3}, 5.4 \% \mathrm{MgO}, 1.0 \% \mathrm{Fe}_{2} \mathrm{O}_{3}$ and some minor constituents of titanium, sulfur and phosphor oxides. The effect of chemical compositions in BFS was considered in the process of thermodynamic calculation, and the species of slag solid phase were shown in Table 2. The existence of BFS would have a significant impact on coal gasification, and compositions of syngas would be different from the coal gasification 
reaction without BFS [36].

The coal gasification reaction was a thermal-chemical process in which the solid fuels were converted to combustible gases by partial oxidization with $\mathrm{H}_{2} \mathrm{O}(\mathrm{g})$ and/or $\mathrm{CO}_{2}$. The results were interpreted based on the following reversible chemical reactions simplified which occurred in the coal gasification reaction.

Boudouard reaction (BD)

$\mathrm{C}+\mathrm{CO}_{2} \leftrightharpoons 2 \mathrm{CO} ; \Delta H_{\mathrm{r}}=172 \mathrm{~kJ} / \mathrm{kmol}$

Methane formation reaction $(\mathrm{MF})$

$\mathrm{C}+2 \mathrm{H}_{2} \leftrightharpoons \mathrm{CH}_{4} ; \Delta H_{\mathrm{r}}=-75 \mathrm{~kJ} / \mathrm{kmol}$

Primary water gas reaction (PWG)

$\mathrm{C}+\mathrm{H}_{2} \mathrm{O} \leftrightharpoons \mathrm{CO}+\mathrm{H}_{2} ; \Delta H_{\mathrm{r}}=131 \mathrm{~kJ} / \mathrm{kmol}$

Methane reforming reaction (MR)

$\mathrm{CH}_{4}+\mathrm{H}_{2} \mathrm{O} \leftrightharpoons \mathrm{CO}+3 \mathrm{H}_{2} ; \Delta H_{\mathrm{r}}=206 \mathrm{~kJ} / \mathrm{kmol}$

Water gas shift reaction (WGS)

$\mathrm{CO}+\mathrm{H}_{2} \mathrm{O} \leftrightharpoons \mathrm{CO}_{2}+\mathrm{H}_{2} ; \Delta H_{\mathrm{r}}=-41 \mathrm{~kJ} / \mathrm{kmol}$

Meanwhile, there were some specific reactions occurred when the BFS existed in the process of coal gasification. It would have a significant impact on the gasification reaction rate and the composition of syngas.

$\mathrm{CaO}+1 / 2 \mathrm{O}_{2} \rightarrow \mathrm{CaO}_{2}$

$\mathrm{CaO}_{2}+\mathrm{C} \rightarrow \mathrm{CaO}+\mathrm{CO}$

$\mathrm{Fe}_{\mathrm{m}} \mathrm{O}_{\mathrm{n}}+\mathrm{CO}_{2} \rightarrow \mathrm{Fe}_{\mathrm{m}} \mathrm{O}_{\mathrm{n}+1}+\mathrm{CO}$

$\mathrm{Fe}_{\mathrm{m}} \mathrm{O}_{\mathrm{n}+1}+\mathrm{C} \rightarrow \mathrm{Fe}_{\mathrm{m}} \mathrm{O}_{\mathrm{n}}+\mathrm{CO}$ 
The parametric analysis of coal gasification was based on the pressure, temperature, $\mathrm{CD} / \mathrm{C}$ ratio $\left(\mathrm{CO}_{2} / \mathrm{C}\right.$ ratio $)$ and $\mathrm{S} / \mathrm{C}$ ratio $\left(\mathrm{H}_{2} \mathrm{O} / \mathrm{C}\right.$ ratio $)$ in carbon conversion, $\mathrm{CO}_{2}$ conversion, $\mathrm{H}_{2} \mathrm{O}$ conversion, $\mathrm{H}_{2}$ yield and $\mathrm{CO}$ yield $[48,49]$.

$$
\begin{aligned}
& \text { Carbon conversion }=\frac{n_{\mathrm{C}, \text { in }}-n_{\mathrm{C}, \text { out }}}{n_{\mathrm{C}, \text { in }}} \times 100 \% \\
& \mathrm{CO}_{2} \text { conversion }=\frac{n_{\mathrm{CO}_{2, \text { in }}}-n_{\mathrm{CO}_{2, \text { out }}}}{n_{\mathrm{CO}_{2, \text { in }}}} \times 100 \% \\
& \mathrm{H}_{2} \mathrm{O} \text { conversion }=\frac{n_{\mathrm{H}_{2} \mathrm{O}_{(\mathrm{g}, \text { in }}}-n_{\mathrm{H}_{2} \mathrm{O}_{(\mathrm{g}, \text { out }}}}{n_{\mathrm{H}_{2} \mathrm{O}_{(\mathrm{g}, \text { in }}}} \times 100 \% \\
& \mathrm{H}_{2} \text { Yield }=\frac{n_{\mathrm{H}_{2, \text { out }}}}{n_{\mathrm{H}_{2, \text { stoic }}}} \times 100 \% \\
& \mathrm{CO} \text { Yield }=\frac{n_{\mathrm{CO}, \text { out }}}{n_{\mathrm{CO}, \text { stoic }}} \times 100 \%
\end{aligned}
$$

\section{Results and discussions}

In this section, we first shall present the thermodynamic analysis results of synergistic coal gasification with $\mathrm{CO}_{2}$ and $\mathrm{H}_{2} \mathrm{O}$ using BFS as heat carrier. The steady state simulation developed was tested by simulating variation of carbon conversion, $\mathrm{CO}_{2}$ conversion and $\mathrm{H}_{2} \mathrm{O}$ conversion, $\mathrm{H}_{2}$ yield and $\mathrm{CO}$ yield with the changing of pressure, temperature, $\mathrm{CD} / \mathrm{C}$ ratio and $\mathrm{S} / \mathrm{C}$ ratio. Finally, the production syngas applications were also investigated by changing the relative $\mathrm{CD} / \mathrm{C}$ ratio and $\mathrm{S} / \mathrm{C}$ ratio modify the $\mathrm{H}_{2} / \mathrm{CO}$ ratio.

3.1 Effect of pressure on coal gasification reaction

Fig. 1 showed the effect of various operation pressures on the performance of carbon conversion, $\mathrm{CO}_{2}$ conversion, $\mathrm{H}_{2}$ yield and $\mathrm{CO}$ yield from $0.1 \mathrm{MPa}$ to $10 \mathrm{MPa}$ 
at $800{ }^{\circ} \mathrm{C}$ and $\mathrm{CD} / \mathrm{C}$ of 1.0 . It was observed that the conversion of carbon and the yield of $\mathrm{H}_{2}$ and $\mathrm{CO}$ were significantly suppressed by the increasing pressure. It was because that the volume contracted with the pressure increasing based on the Le Chatelier's principle. Both BD reaction and PWG reaction shifted to the left and CO and $\mathrm{H}_{2}$ were largely consumed, and carbon and $\mathrm{CO}_{2}$ were generated. That was to say, the increasing pressure did not play a good role in promoting coal gasification with $\mathrm{CO}_{2}$ using BFS as heat carrier. Therefore, the atmospheric pressure was preferable pressure for coal gasification. The atmospheric pressure was also very beneficial to solve the problem at high pressure (greater than $1 \mathrm{MPa}$ ) of the most Fischer-Tropsch synthesis industrial production process $[50,51]$.
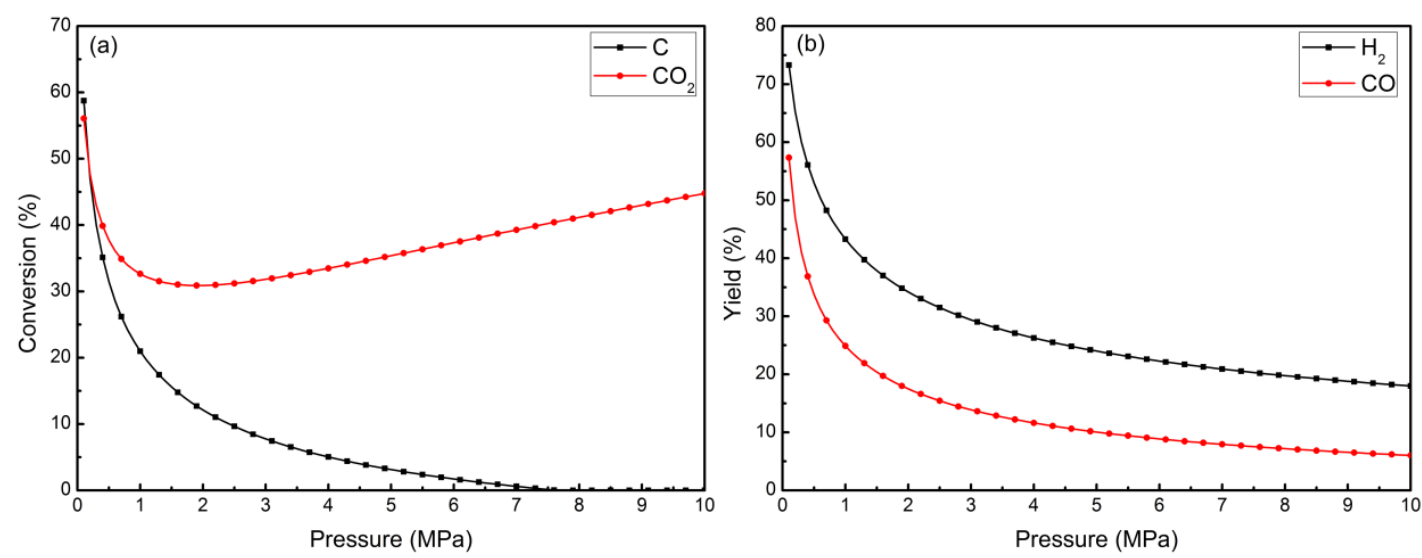

Fig. 1 Effect of pressure on the equilibrium of the Carbon, $\mathrm{CO}_{2}$ conversions and $\mathrm{H}_{2}, \mathrm{CO}$ yield for the coal $/ \mathrm{CO}_{2}$ gasification reaction at $800^{\circ} \mathrm{C}$

\subsection{Effect of steam addition on coal gasification reaction}

Fig. 2 showed the effect of steam addition on the equilibrium of carbon, $\mathrm{CO}_{2}$ and $\mathrm{H}_{2} \mathrm{O}$ conversions for the $\mathrm{C} / \mathrm{CO}_{2} / \mathrm{H}_{2} \mathrm{O}$ gasification reaction at different temperatures with $\mathrm{C} / \mathrm{CO}_{2}=1.0$ and atmospheric pressure. It could be seen from Fig. 2(a), steam addition had a significant effect on the carbon conversion in the process of coal 
gasification. The carbon conversion increased steadily with increasing of steam addition when the temperature was lower than $800{ }^{\circ} \mathrm{C}$. This result was consistent with the work of Jayaraman [52] and Roberts [14]. The reactivity of coal in $\mathrm{CO}_{2}$ ambiance was much lower than that in steam. Meanwhile, the coal gasification rate strongly depended on the mass of steam, the more steam addition was in the gasification process, the stronger reactivity was. However, the carbon conversion was ignored with steam addition when the gasification temperature was above $800{ }^{\circ} \mathrm{C}$. It was because that the carbon conversion reached $100 \%$ with the reaction of BD and PWG, which was limited by the mass of gasification agent [48].

Compared with the transformation of carbon conversion with steam addition, the $\mathrm{CO}_{2}$ had its unique change rule. With increasing temperature, $\mathrm{CO}_{2}$ conversion decreased firstly and then increased, and its value reached to the minimum at about $650{ }^{\circ} \mathrm{C}$, as shown in Fig. 2(b). This result was due to the effect of BFS in the gasification with $\mathrm{BFS}$ as heat carrier. With the presence of $\mathrm{CaO}$ in $\mathrm{BFS}, \mathrm{CO}_{2}$ was absorbed and converted to $\mathrm{CaCO}_{3}$, so $\mathrm{CO}_{2}$ conversion was very high when the temperature was lower than $650{ }^{\circ} \mathrm{C}$. With increasing temperature, $\mathrm{CO}_{2}$ was released from $\mathrm{CaCO}_{3}$ and reacted with carbon to produce $\mathrm{CO}[33,36,53] . \mathrm{CO}_{2}$ conversion increased with the increasing of temperature. Meanwhile, the reactivity of coal also increased significantly with the existence of $\mathrm{CaO}$ in BFS [33]. However, steam addition decreased $\mathrm{CO}_{2}$ conversion and its effect was very remarkable. For example, $\mathrm{CO}_{2}$ conversion was $86.3 \%$ when the $\mathrm{S} / \mathrm{C}=0$ at $1000{ }^{\circ} \mathrm{C}$, but it decreased to $28.7 \%$ when the $\mathrm{S} / \mathrm{C}=3.0$. It was because that both $\mathrm{CO}_{2}$ and steam acted as the co-agent in 
process of gasification. The carbon reacted with steam, instead of $\mathrm{CO}_{2}$ with the steam addition increasing. It was because that $\mathrm{H}_{2} \mathrm{O}$ and $\mathrm{CO}_{2}$ would be scrambling for some active sites on coal char and $\mathrm{H}_{2} \mathrm{O}$ was more competitive than $\mathrm{CO}_{2}[14,19,22]$. Then from the thermodynamic, PWG and WGS reaction were promoted by adding steam, and a certain amount of $\mathrm{CO}_{2}$ was generated, so $\mathrm{CO}_{2}$ conversion decreased significantly even to be the negative when the $\mathrm{S} / \mathrm{C}$ ratio was above 2.0.
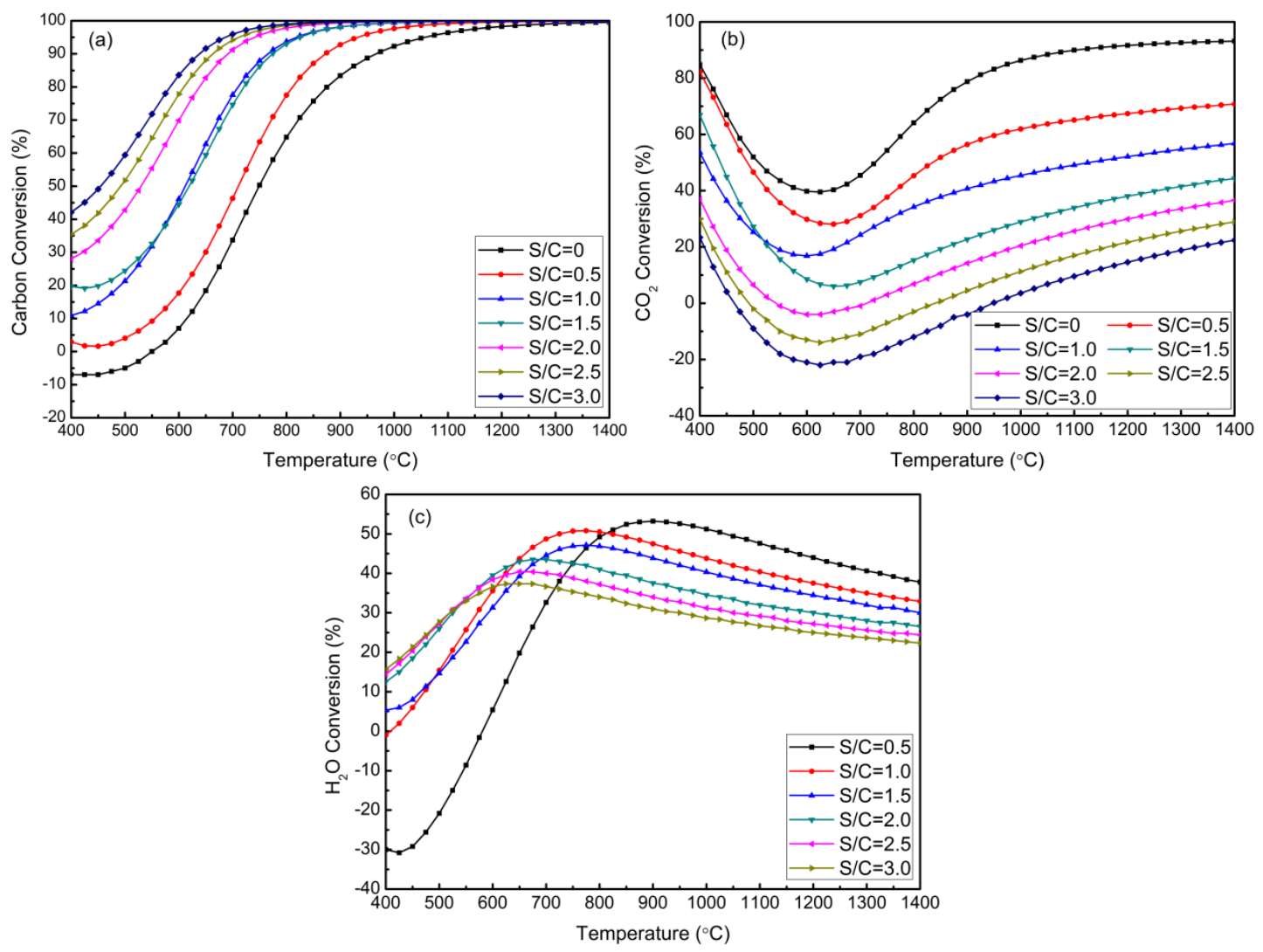

Fig. 2 Effect of steam addition on the equilibrium of the Carbon, $\mathrm{CO}_{2}$ and $\mathrm{H}_{2} \mathrm{O}$ conversions for the combined $\mathrm{C} / \mathrm{CO}_{2} / \mathrm{H}_{2} \mathrm{O}$ gasification reaction at different temperatures with $\mathrm{C} / \mathrm{CO}_{2}=1.0$ and atmospheric pressure

Although it was benefited to the carbon conversion in process of coal gasification using BFS as heat carrier, the extra steam was not favored for $\mathrm{H}_{2} \mathrm{O}$ conversion and the gasification reaction. It could be seen from Fig. 2(c), $\mathrm{H}_{2} \mathrm{O}$ conversion decreased with 
the increasing of the S/C ratio at the higher temperature. Based on the Shabbar [41] and Duan [36] results, the extra steam was introduced than necessary for gasification, which caused a large amount of energy consumption and decreased the gasification efficiency. Therefore, it was necessary to manage the amount of addition steam appropriately in process of gasification.

The effect of steam addition on the equilibrium of $\mathrm{H}_{2}$ yield (\%), and $\mathrm{CO}$ yield (\%) for the $\mathrm{C} / \mathrm{CO}_{2} / \mathrm{H}_{2} \mathrm{O}$ gasification reaction at different temperatures and atmospheric pressure with $\mathrm{CD} / \mathrm{C}=1.0$ were presented in Fig. 3. It was observed from the figure, the effect of steam had slight influence on both $\mathrm{H}_{2}$ and $\mathrm{CO}$ yields at $700{ }^{\circ} \mathrm{C}$. On the contrast, there was a significant reduction of $\mathrm{H}_{2}$ and $\mathrm{CO}$ yields with steam addition when the temperature was higher than $700{ }^{\circ} \mathrm{C}$. However, the change trend of $\mathrm{H}_{2}$ yield was different from with/without steam addition. At $\mathrm{S} / \mathrm{C}$ ratio of $0, \mathrm{H}_{2}$ yield reached the maximum and remained the same with the temperature higher than $900{ }^{\circ} \mathrm{C}$. With increasing temperature, $\mathrm{H}_{2}$ yield increased firstly and then decreased, and its yield reached to the maximum at $700-900{ }^{\circ} \mathrm{C}$, which was varied from $\mathrm{S} / \mathrm{C}$ ratios. It was because that PWG and MR reaction resulted favorably in the higher production of $\mathrm{H}_{2}$ with the increasing temperature. But $\mathrm{H}_{2}$ yield decreased when the temperature reached to a value, it was due to the rWGS reaction was promoted and the net effect was on the higher $\mathrm{H}_{2}$ yield at lower temperature followed by a gradual decrease. Meanwhile, $\mathrm{CO}$ yield also reached to a relatively high value at $800-1000{ }^{\circ} \mathrm{C}$ and kept stable with the increasing temperature. Therefore, by analysis above, it was necessary to control the S/C ratio reasonably, so as to increase $\mathrm{H}_{2}$ yield and change $\mathrm{H}_{2} / \mathrm{CO}$ (in the range of 
1-3 was desired for use in petrochemical manufacture). The temperature should be controlled at $700-1000{ }^{\circ} \mathrm{C}$ to get the maximum output of $\mathrm{H}_{2}$ and $\mathrm{CO}$. Meanwhile, it was beneficial to recover the waste heat of BFS when gasification reaction proceeding with slag as heat carrier.
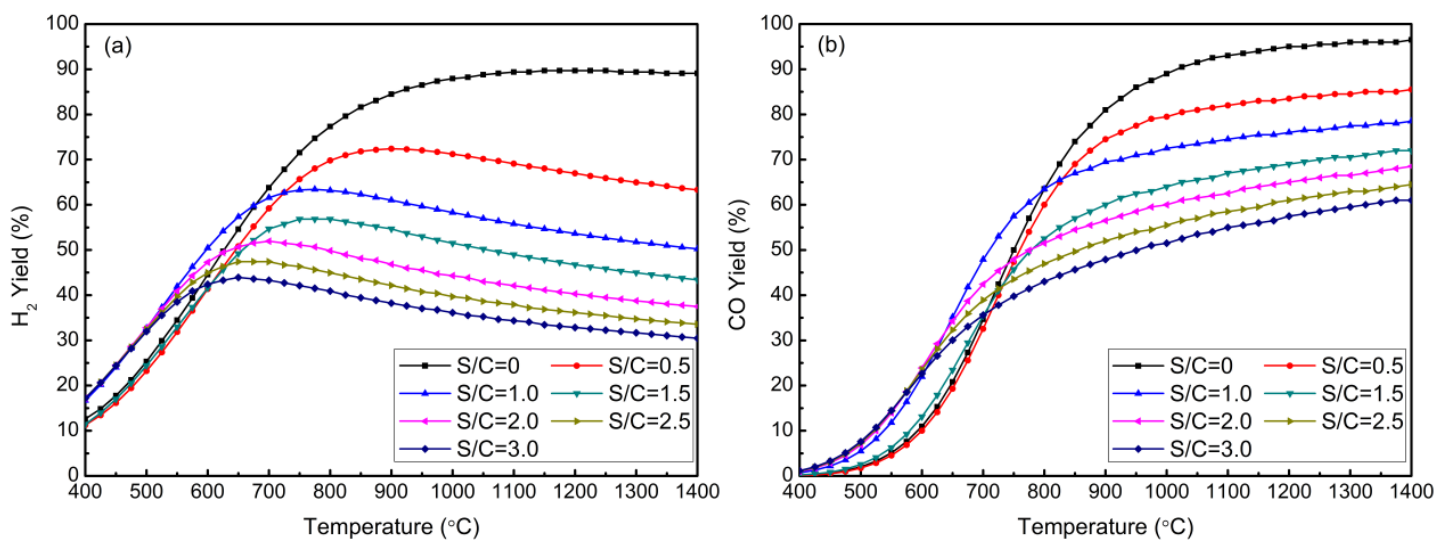

Fig. 3 Effect of steam addition on the equilibrium of the $\mathrm{H}_{2}$ yield (\%), and $\mathrm{CO}$ yield (\%) for the combined $\mathrm{C} / \mathrm{CO}_{2} / \mathrm{H}_{2} \mathrm{O}$ gasification reaction at different temperatures with $\mathrm{C} / \mathrm{CO}_{2}=1.0$ and atmospheric pressure

\subsection{Effect of gasification agent feed ratio on coal gasification reaction}

According to obtained results from above, the thermodynamic analysis was performed at different feed ratio $(\mathrm{CD} / \mathrm{S} / \mathrm{C}=0-2 / 0-2 / 1)$ and different temperatures of 700-1000 ${ }^{\circ} \mathrm{C}$ to achieve the change of carbon, $\mathrm{CO}_{2}$ and $\mathrm{H}_{2} \mathrm{O}$ conversion, $\mathrm{H}_{2}$ and $\mathrm{CO}$ yield in the process of synergistic coal gasification reaction using BFS as heat carrier. In Fig. 4, it was observed that increasing the feed ratio of $\mathrm{CD} / \mathrm{C}$ and $\mathrm{S} / \mathrm{C}$ were benefited for carbon conversion at $700{ }^{\circ} \mathrm{C}$ or $1000{ }^{\circ} \mathrm{C}$. The carbon conversion increased significantly at lower $\mathrm{CD} / \mathrm{C}$ and $\mathrm{S} / \mathrm{C}$ ratios under $700-1000{ }^{\circ} \mathrm{C}$. However, the change of carbon conversion was stable and near to $100 \%$ when $\mathrm{CD} / \mathrm{C}$ and $\mathrm{S} / \mathrm{C}$ ratios were higher. Under these conditions, the effect of temperature on carbon 
conversion was negligible, especially at $900{ }^{\circ} \mathrm{C}$ and $1000^{\circ} \mathrm{C}$. That was to say, in the process of coal gasification using BFS as heat carrier, it was reasonable to control the temperature at $800-900{ }^{\circ} \mathrm{C}$ so as to guarantee the coal gasification completely and recover the waste heat of BFS as much as possible.
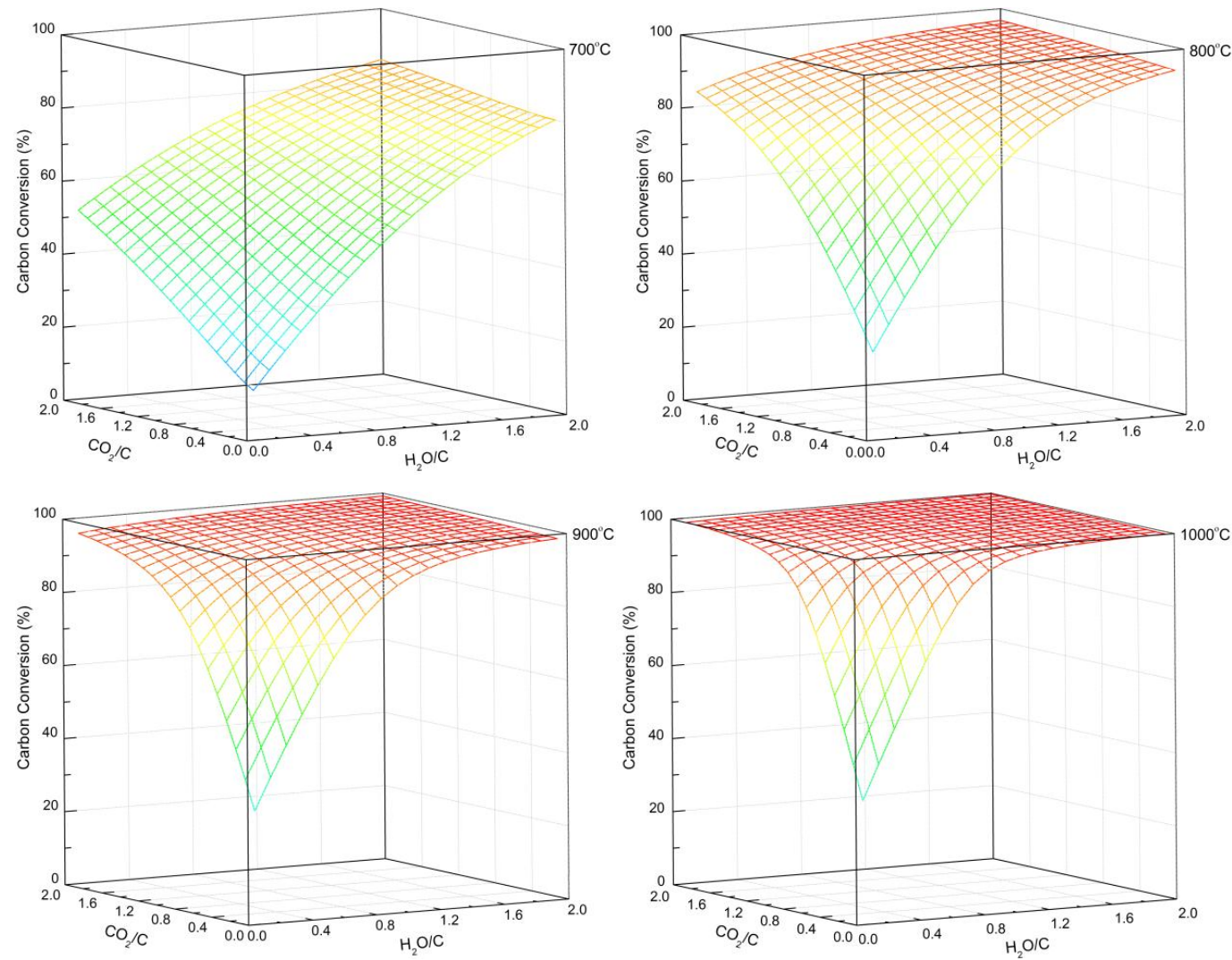

(a) Carbon conversion at different temperatures
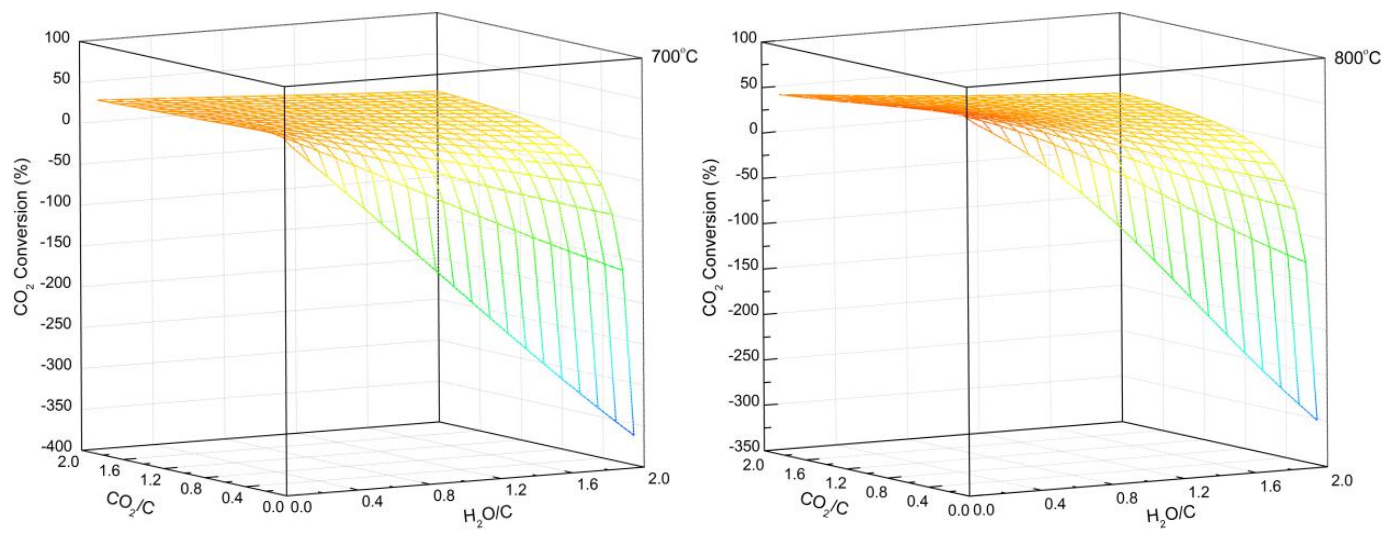

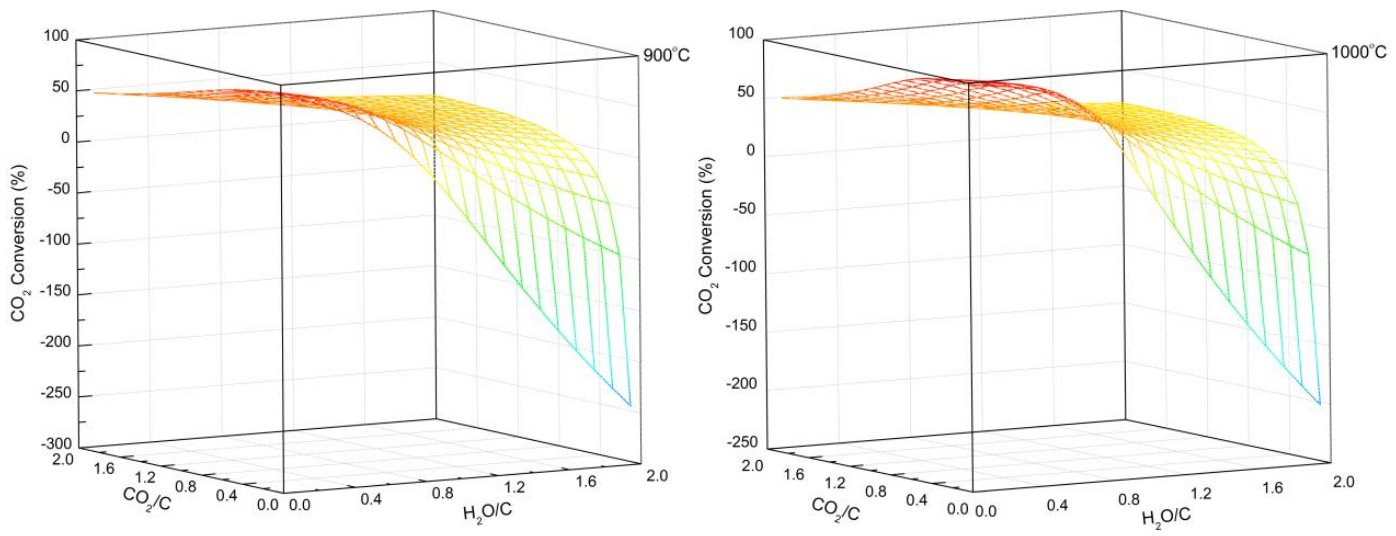

(b) $\mathrm{CO}_{2}$ conversion at different temperatures
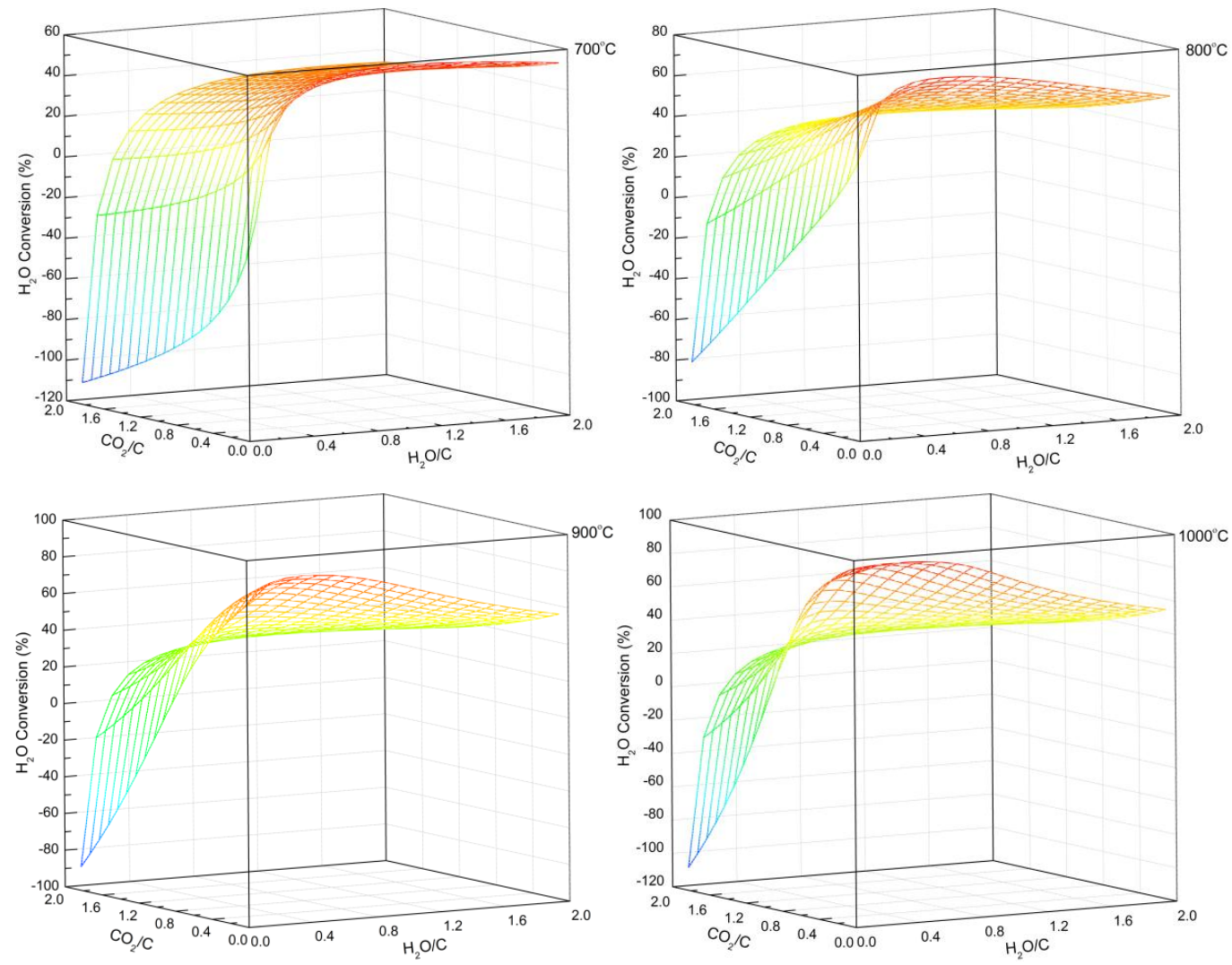

(c) $\mathrm{H}_{2} \mathrm{O}$ conversion at different temperatures

Fig. 4 The equilibrium of the (a) Carbon conversion (\%), (b) $\mathrm{CO}_{2}$ conversion (\%) and (c) $\mathrm{H}_{2} \mathrm{O}$ conversion (\%) for the combined $\mathrm{C} / \mathrm{CO}_{2} / \mathrm{H}_{2} \mathrm{O}$ gasification reaction for various $\mathrm{CO}_{2} / \mathrm{C}$ and $\mathrm{H}_{2} \mathrm{O} / \mathrm{C}$ at different temperatures and atmospheric pressure

$\mathrm{CO}_{2}$ conversion increased with the increasing of temperature for all feed ratios. It was because that the endothermic $\mathrm{BD}$ reaction was accelerated by the higher 
temperature. Whereas, it was negative for $\mathrm{CO}_{2}$ conversion when the low $\mathrm{CD} / \mathrm{C}$ ratio and high S/C ratio were added in the system of coal gasification, even released more $\mathrm{CO}_{2}$ than added. The existence of the large amount of steam caused the domination of PWG reaction and WGS reaction and produced a large amount of $\mathrm{CO}_{2}$. That was to say, it was a disadvantage to the utilization of $\mathrm{CO}_{2}$ in the process of coal gasification when exceed steam was added in the gasification system. As for steam conversion, it was consisted with the change of $\mathrm{CO}_{2}$ conversion at different temperatures, $\mathrm{CD} / \mathrm{C}$ ratios and $\mathrm{S} / \mathrm{C}$ ratios. Therefore, considering the above analysis, $\mathrm{CO}_{2}$ and $\mathrm{H}_{2} \mathrm{O}$ were obviously competitive and mutual inhibition in the process of synergistic coal gasification using BFS as heat carrier.

The effect of the equilibrium of $\mathrm{H}_{2}$ yield and $\mathrm{CO}$ yield for $\mathrm{C} / \mathrm{CO}_{2} / \mathrm{H}_{2} \mathrm{O}$ gasification reaction for various $\mathrm{CD} / \mathrm{C}$ ratios and $\mathrm{S} / \mathrm{C}$ ratios at different temperatures and atmospheric pressure were shown in Fig. 5. It could be seen from Fig. 5, $\mathrm{H}_{2}$ yield and $\mathrm{CO}$ yield increased high temperature at a certain $\mathrm{CD} / \mathrm{C}$ ratio and $\mathrm{S} / \mathrm{C}$ ratio. At $700-1000{ }^{\circ} \mathrm{C}$, it was beneficial to produce $\mathrm{H}_{2}$ and $\mathrm{CO}$ in synergistic coal gasification reaction. It was because that $\mathrm{BD}$ reaction and $\mathrm{PWG}$ reaction promoted producing $\mathrm{H}_{2}$ and $\mathrm{CO}$ when the temperature increased. But with the higher temperature, the effect began to wane and nearly no effect on product yields after a certain stage of temperature, which resulted in the $100 \%$ carbon conversion. The difference was that, $\mathrm{H}_{2}$ yield decreased with the increasing of $\mathrm{CD} / \mathrm{C}$ and $\mathrm{S} / \mathrm{C}$ ratios. As discussed in the previous section, both $\mathrm{CO}_{2}$ and $\mathrm{H}_{2} \mathrm{O}$ acted as co-agent in the process of gasification, and the larger of $\mathrm{CD} / \mathrm{C}$ ratio inhibited the PWG reaction and decreased the utilization 
efficiency of steam. However, with increasing of $\mathrm{CD} / \mathrm{C}$ and $\mathrm{S} / \mathrm{C}$ ratios, $\mathrm{CO}$ yield increased firstly and then decreased. That was to say, it was necessary to reasonably control $\mathrm{CD} / \mathrm{C}$ and $\mathrm{S} / \mathrm{C}$ ratios in synergistic coal gasification using $\mathrm{BFS}$ as heat carrier so as to obtain the more production.
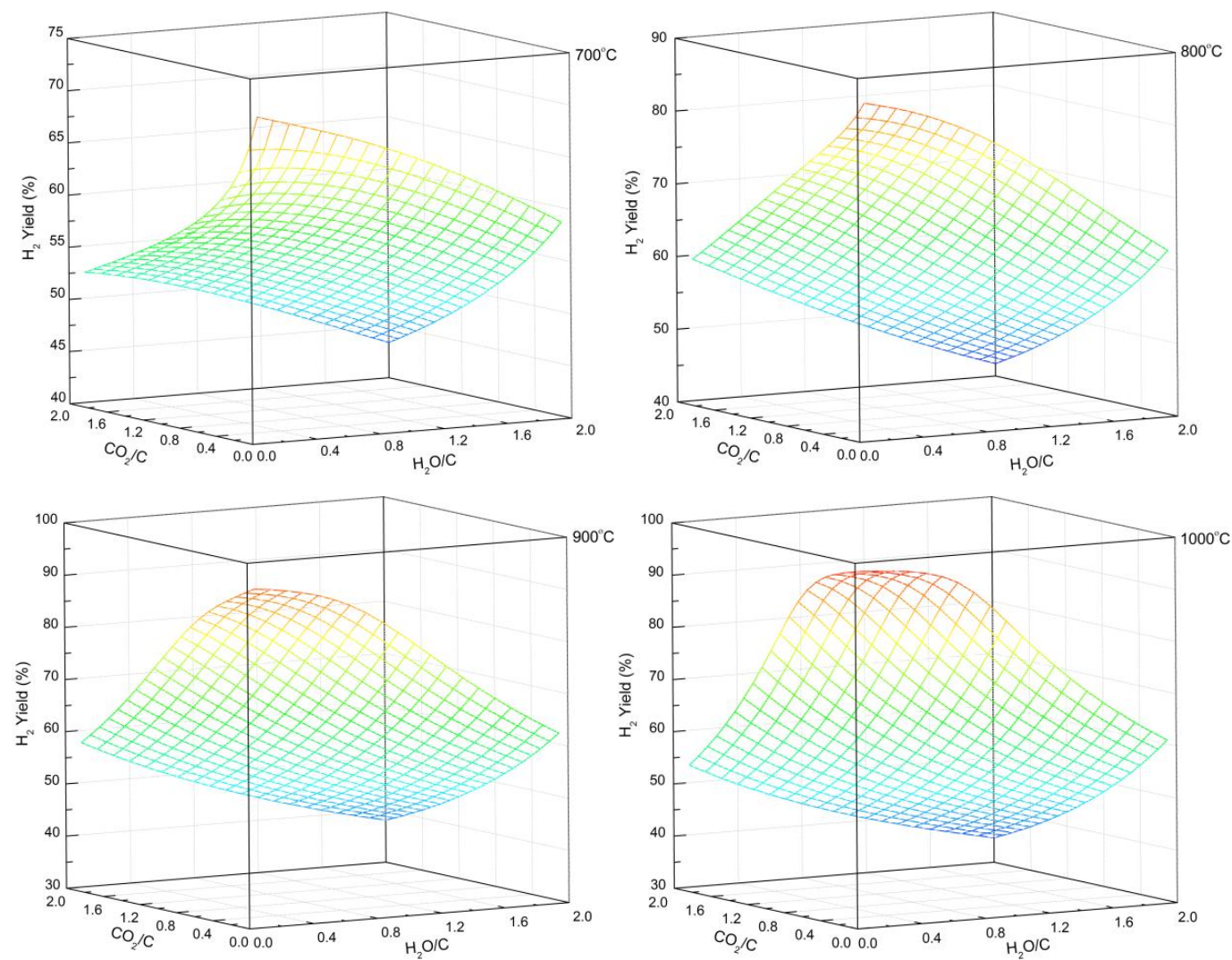

(a) $\mathrm{H}_{2}$ yield at different temperatures
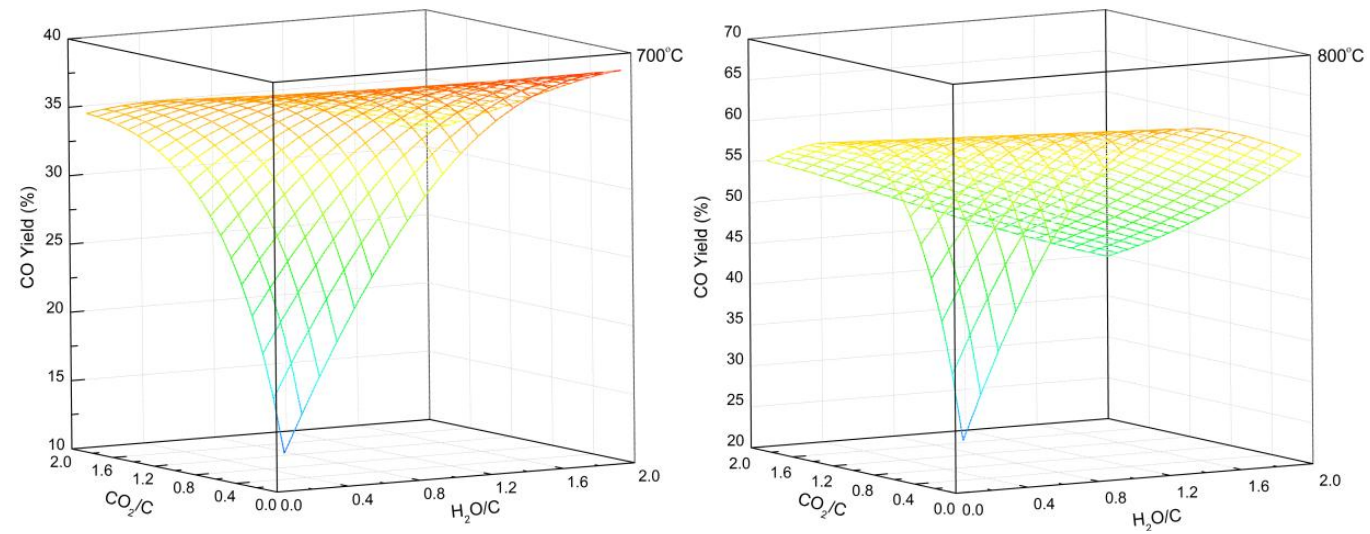

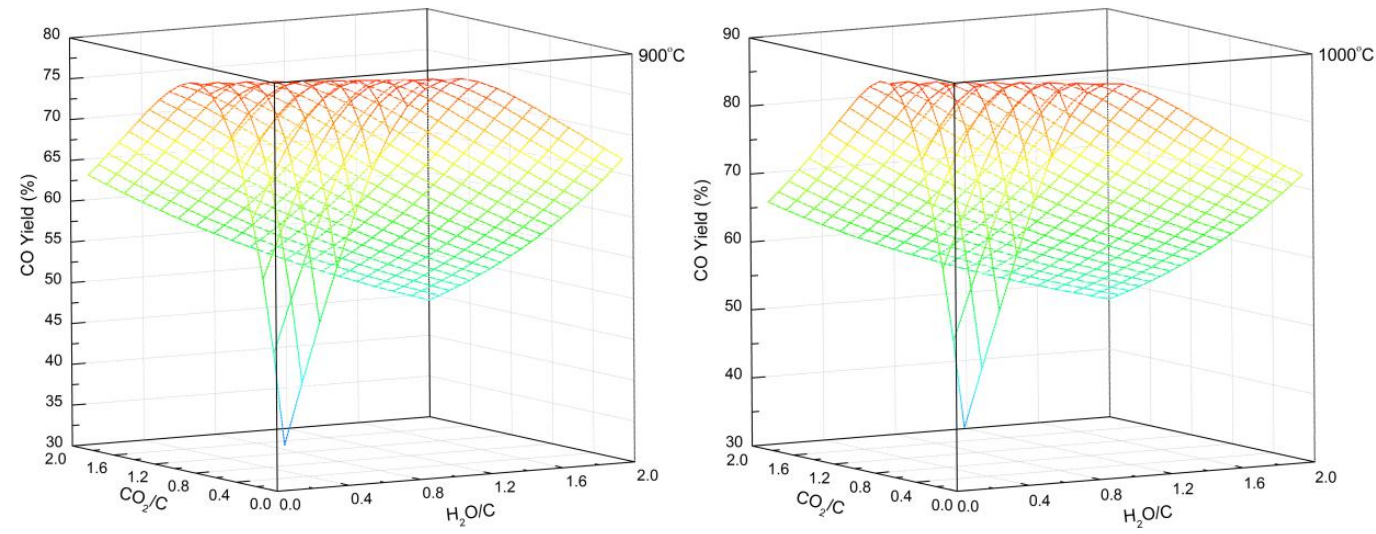

(b) $\mathrm{CO}$ yield at different temperatures

Fig. 5 The equilibrium of the (a) $\mathrm{H}_{2}$ yield (\%), and (b) $\mathrm{CO}$ yield (\%) for the combined $\mathrm{C} / \mathrm{CO}_{2} / \mathrm{H}_{2} \mathrm{O}$ gasification reaction for various $\mathrm{CO}_{2} / \mathrm{C}$ and $\mathrm{H}_{2} \mathrm{O} / \mathrm{C}$ at different temperatures and atmospheric

$$
\text { pressure }
$$

3.4 The controlling of the $\mathrm{CO}_{2} / \mathrm{C}$ ratios and $\mathrm{H}_{2} \mathrm{O} / \mathrm{C}$ ratios for the syngas applications

The coal gasification reaction was a thermal-chemical process aiming at the production of high heating value synthesis gas, a mixture of $\mathrm{H}_{2}$ and $\mathrm{CO}$, which was further utilized in a variety of downstream processes for production of liquid hydrocarbons, carbonylation and hydrogenation or reduction processes $[8,48,54,55]$. Therefore, it was necessary to investigate the effect of $\mathrm{CO}_{2}$ and $\mathrm{H}_{2} \mathrm{O}$ addition (i.e. $\mathrm{CD} / \mathrm{C}$ ratio and $\mathrm{S} / \mathrm{C}$ ratio) in the process of coal gasification.

Fig. 6 showed the equilibrium of $\mathrm{H}_{2} / \mathrm{CO}$ ratio for $\mathrm{C} / \mathrm{CO}_{2} / \mathrm{H}_{2} \mathrm{O}$ gasification reaction for various $\mathrm{CD} / \mathrm{C}$ and $\mathrm{S} / \mathrm{C}$ at $800{ }^{\circ} \mathrm{C}$ and atmospheric pressure. The desirable synthesis gas ratio for used in the manufacture was easily obtained from Fig. 6. The long-chain hydrocarbon synthesis, dimethyl ether synthesis and acetic acid production usually required the synthesis gas with a $\mathrm{H}_{2} / \mathrm{CO}$ ratio close to $1.0[48,56-58]$. As can be seen from Fig. 6, $\mathrm{CD} / \mathrm{C}$ ratio should be controlled lower than 2.5 in the range of $\mathrm{S} / \mathrm{C}=$ 
0 3.0. Meanwhile, $\mathrm{CD} / \mathrm{C}$ ratio should be lower than $\mathrm{S} / \mathrm{C}$ ratio of 0.5 in the process of synergistic coal gasification reaction using BFS as heat carrier.

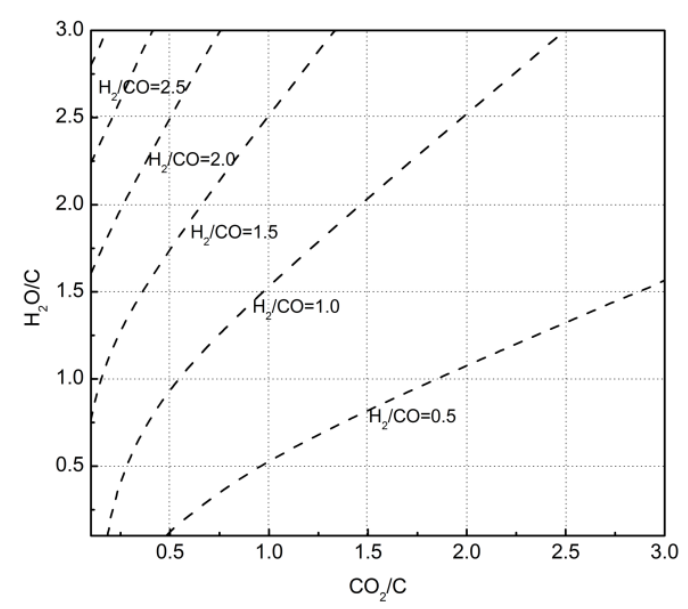

Fig. 6 The equilibrium of the $\mathrm{H}_{2} / \mathrm{CO}$ ratio for the combined $\mathrm{C} / \mathrm{CO}_{2} / \mathrm{H}_{2} \mathrm{O}$ gasification reaction for various $\mathrm{CO}_{2} / \mathrm{C}$ and $\mathrm{H}_{2} \mathrm{O} / \mathrm{C}$ at $800{ }^{\circ} \mathrm{C}$ and atmospheric pressure

Based on the above sections analysis, the total amount of $\mathrm{H}_{2} \mathrm{O}$ and $\mathrm{CO}_{2}$ addition also should reach to a certain amount to make sure the complete carbon conversion. The synthesis gas with a $\mathrm{H}_{2} / \mathrm{CO}$ ratio of 2.0 was desired feedstock for Fischer-Tropsch and methanol syntheses $[59,60]$. In order to obtain the desired syngas, $\mathrm{CD} / \mathrm{C}$ ratio should be lower than 0.75 and $\mathrm{S} / \mathrm{C}$ ratio was higher than 1.5 . At this condition, $\mathrm{PWG}$ and WGS reactions were promoted and BD reaction was inhibited, and production of $\mathrm{H}_{2}$ was improved significantly. The carbon could react completely with $\mathrm{H}_{2} \mathrm{O}$ and $\mathrm{CO}_{2}$ to produce $\mathrm{H}_{2}$ and $\mathrm{CO}$. The syngas with $\mathrm{H}_{2} / \mathrm{CO}$ of 3.0 or more could be used for manufacture of synthetic natural gas as heat production of the SNG (synthetic natural gas) via a thermal-chemical process [61]. For the coal gasification using BFS as heat carrier, it was very hard to obtain the syngas with $\mathrm{H}_{2} / \mathrm{CO}$ of 3.0 in synergistic gasification reaction with $\mathrm{CO}_{2}$ and $\mathrm{H}_{2} \mathrm{O}$. To satisfy the condition of syngas used in the SNG production, $\mathrm{CO}_{2}$ could not be added into the gasification system and $\mathrm{S} / \mathrm{C}$ ratio 
should be higher than 2.7. However, extra steam addition than necessary for gasification would decrease the gasification efficiency and took away a lot of waste heat of BFS, the same result was obtained by Wang [62] and Duan [36]. So, it was necessary to control the $\mathrm{S} / \mathrm{C}$ ratio in the range of $2.7 \sim 3.0$ in process of coal gasification.

The production syngas could be used for the power generation in turbines, heating and metallurgic enterprises production and so on. In such conditions, the superior LHV (lower heating value) of the production syngas was expected. Fig. 7 showed the LHV of production syngas for $\mathrm{C} / \mathrm{CO}_{2} / \mathrm{H}_{2} \mathrm{O}$ gasification reaction for various $\mathrm{CD} / \mathrm{C}$ and $\mathrm{S} / \mathrm{C}$ at $800{ }^{\circ} \mathrm{C}$ and atmospheric pressure.

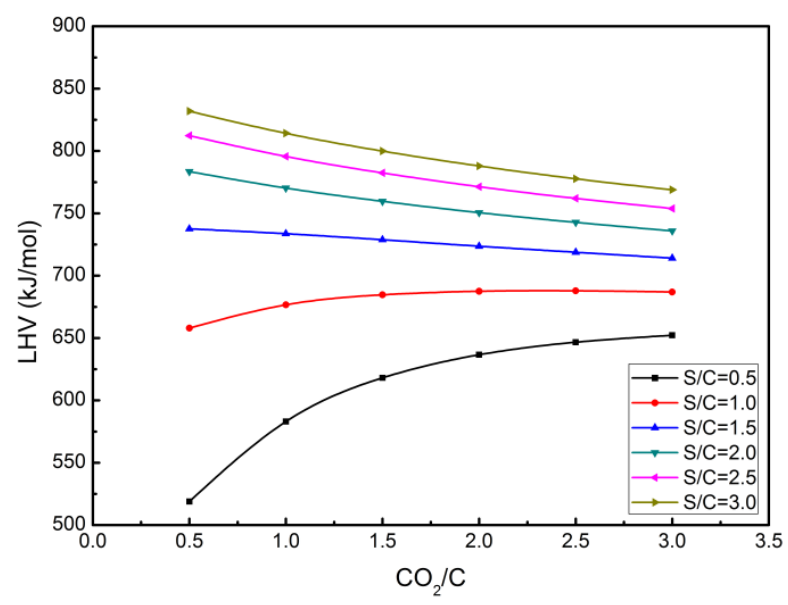

Fig. 7 The LHV of the production syngas for the combined $\mathrm{C} / \mathrm{CO}_{2} / \mathrm{H}_{2} \mathrm{O}$ gasification reaction for various $\mathrm{CO}_{2} / \mathrm{C}$ and $\mathrm{H}_{2} \mathrm{O} / \mathrm{C}$ at $800^{\circ} \mathrm{C}$ and atmospheric pressure

As could be seen from the Fig. 7, the LHV of the production syngas increased with S/C increasing at a certain $\mathrm{CD} / \mathrm{C}$ ratio. It was because that PWG reaction and WGS reaction were promoted with the increasing of $\mathrm{S} / \mathrm{C}$ ratio, and the more $\mathrm{H}_{2}$ was produced. It was beneficial to increase the LHV of the syngas when steam was added into the system as the gasification agent. However, the effect of $\mathrm{CO}_{2}$ on the LHV of 
the syngas was different from that of steam. The LHV of the syngas increased firstly and then was steady with the increasing of $\mathrm{CD} / \mathrm{C}$ ratio at $\mathrm{S} / \mathrm{C}$ ratios lower than 1.5 . On the contrary, the LHV of the syngas decreased with the increasing of CD/C at the S/C ratios higher than 1.5. That was to say, the $\mathrm{CD} / \mathrm{C}$ ratio of $2.5 \sim 3.0$ was suitable for the gasification to produce syngas with higher LHV at S/C ratio of $0.5 \sim 1.0$. The CD/C ratio at 0.5 was suitable when the $\mathrm{S} / \mathrm{C}$ ratio was higher than 1.5 . In addition to using the syngas in the petrochemical manufacture, it could be used as fuel in fuel cells (eg. SOFC (solid oxide fuel cells) and PEMFC (polymer electrolyte membrane fuel cells)) $[5,63,64]$. However, the content of $\mathrm{CO}$ and $\mathrm{H}_{2} \mathrm{O} / \mathrm{CO}$ in the syngas should be strictly restricted. The syngas need to be processed through WGS reactor to reduce CO content by converting it to $\mathrm{H}_{2}$ and further $\mathrm{CO}$ reduction was achieved by preferential oxidation reactors.

\section{Conclusions}

Thermodynamic analysis of the coal gasification using BFS as heat carrier was conducted by the method of Gibbs free energy minimization. The calculation was carried out at $0.1 \mathrm{MPa}$ and $10 \mathrm{MPa}, 400{ }^{\circ} \mathrm{C}-1400{ }^{\circ} \mathrm{C}, \mathrm{CD} / \mathrm{C}$ ratios and $\mathrm{S} / \mathrm{C}$ ratios of 0.1-3.0 and 0.1-3.0, respectively. The results showed that the atmospheric pressure was preferable for the synergistic coal gasification reaction. The high temperature was benefited to conduct the coal gasification reaction, but excessively high temperature inhibited the production of syngas and decreased the utilization efficiency of waste heat. The optimal temperature of synergistic coal gasification should be controlled at 
800-900 ${ }^{\circ} \mathrm{C}$. With the addition of steam, the carbon conversion and $\mathrm{H}_{2} / \mathrm{CO}$ increased considerably whereas $\mathrm{CO}_{2}$ and $\mathrm{H}_{2} \mathrm{O}$ conversions, $\mathrm{H}_{2}$ yield and $\mathrm{CO}$ yield decreased. The addition of $\mathrm{H}_{2} \mathrm{O}$ and $\mathrm{CO}_{2}$ to the feed mixture could lead to a reduction of carbon residue and increase of the production of $\mathrm{H}_{2}$ and $\mathrm{CO}$, respectively. In addition, the production syngas could be used for many industrial manufactures. The needed $\mathrm{H}_{2} / \mathrm{CO}$ ratio in the syngas could be modified effectively by changing the relative $\mathrm{CD} / \mathrm{C}$ ratio and $\mathrm{S} / \mathrm{C}$ ratio.

\section{Nomenclature}

$n_{i, i n}=$ The mole of the $i$ in the coal gasification reaction system, mol;

$n_{i, \text { out }}=$ The mole of the $i$ out of the coal gasification reaction system, mol;

$n_{i, \text { stoic }}=$ The mole of stoichiometric amount of produced $i$, mol;

$G_{T, P}^{t}=$ The total Gibbs free energy;

$\mu_{i}=$ The chemical potential of species $i$;

$G_{f, i}^{0}=$ The standard Gibbs free energy of formation of species;

$R=$ The universal gas constant, $8.314 \mathrm{~kJ} / \mathrm{kmol} \cdot \mathrm{K}$;

$y_{i}=$ The mole fraction of gas species;

$a_{i j}=$ The number of atoms of the $j$ th element in each mole of the $i$ th species;

$A_{j}=$ The total number of atoms of the $j$ th element in the system;

$k=$ The total number of atoms;

$\Delta \bar{H}_{f, i}^{0}=$ The values of the standard enthalpy of formationt temperature $T, \mathrm{~kJ} / \mathrm{kmol}$;

$\Delta S_{f, i}^{0}=$ The standard entropy of formation at temperature $T, \mathrm{~kJ} / \mathrm{kmol} \cdot \mathrm{K}$; 
$\bar{C}_{P}=$ The heat capacity at constant pressure for the standard state, $\mathrm{kJ} / \mathrm{kmol} \cdot \mathrm{K}$;

$T_{o}=$ The inlet temperature of the reactants, $\mathrm{K}$.

\author{
Abbreviations \\ BFS = Blast furnace slag \\ DT coal $=$ Datong coal \\ $\mathrm{S} / \mathrm{C}=$ Steam to carbon ratio \\ $\mathrm{CD} / \mathrm{C}=$ Carbon dioxide to carbon ratio \\ $\mathrm{BD}=$ Boudouard reaction \\ $\mathrm{MF}=$ Methane formation reaction \\ $\mathrm{PWG}=$ Primary water gas reaction \\ $\mathrm{MR}=$ Methane reforming reaction \\ WGS $=$ Water gas shift reaction \\ $\mathrm{SNG}=$ Synthetic natural gas \\ $\mathrm{LHV}=$ Lower heating value
}

\title{
Acknowledgements
}

This research was supposed by The National Natural Science Foundation of China (51274066, 51304048), The National Key Technologies R\&D Program of China (2013BAA03B03), The National Science Foundation for Post-doctoral Scientists of China (2015M571322), The Fundamental Research Funds for the Central Universities (N130402019). 


\section{References}

[1]. Yoon SJ, Lee Jae-Goo. Hydrogen-rich syngas production through coal and charcoal gasification using microwave steam and air plasma torch. International Journal of Hydrogen Energy 2012; 37: 17903-17100.

[2]. Ge ZW, Jin H, Guo LJ. Hydrogen production by catalytic gasification of coal in supercritical water with alkaline catalysts: Explore the way to complete gasification of coal. International Journal of Hydrogen Energy 2014; 39(34): 19583-19592.

[3]. Xu CF, Hu S, Xiang J, Yang HP, Sun LS, Su S, Wang BW, Chen QD, He LM. Kinetic models comparison for steam gasification of coal/biomass blend chars. Bioresource Technology 2014; 171: 253-259.

[4]. Prabu V. Integration of in-suit $\mathrm{CO}_{2}$-oxy coal gasification of coal with production of high-quality syngas in a simulated pilot system for in suit gasification. Applied Energy 2015; 140: 1-13.

[5]. Ganesh R. Kale, Bhaskar D. Kulkarni, Ranjit N. Chavan. Combined gasification of lignite coal: Thermodynamic and application study. Journal of the Taiwan Institute of Chemical Engineers 2013; 635: 11-21.

[6]. Le ST, Kolaczkowski ST. Steam gasification of a refuse derived char: Reactivity and kinetics. Chemical Engineering Research and Design 2015; 102: 389-398.

[7]. Gokon N, Izawa T, Abe T, Kodama T. Steam gasification of coal cokes in an internally circulating fluidized bed of thermal storage material for solar 
thermochemical processes. International Journal of Hydrogen Energy 2014; 39(21): 11082-11093.

[8]. Nematollahi B, Rezaei M, Nemati Lay E, Khajenoori M. Thermodynamic analysis of combined reforming process using Gibbs energy minimization method: In view of solid carbon formation. Journal of Natural Chemistry 2012;21: 694-702.

[9]. Wang QH, Rong N, Fan HT, Meng YJ, Fang MX, Cheng LM, Cen KF. Enhanced hydrogen-rich gas production from steam gasification of coal in a pressurized fluidized bed with $\mathrm{CaO}$ as a $\mathrm{CO}_{2}$ sorbent. International Journal of Hydrogen Energy 2014; 39(11): 5781-5792.

[10]. Liu L, Cao Y, Liu QC. Kinetics studies and structure characteristics of coal char under pressurized $\mathrm{CO}_{2}$ gasification conditions. Fuel 2015; 146: 103-110.

[11]. Kim RG, Hwang $\mathrm{CW}$, Jeon $\mathrm{CH}$. Kinetic of coal char gasification with $\mathrm{CO}_{2}$ : impact of internal/external diffusion at high temperature and elevated pressure. Applied Energy 2014; 129: 299-307.

[12]. Chen SY, Wang D, Xue ZP, Sun XY, Xiang WG. Calcium looping gasification for high-concentration hydrogen production with $\mathrm{CO}_{2}$ capture in a novel compact fluidized bed: simulation and operation requirements. International Journal of Hydrogen Energy 2011; 36(8): 4887-4899.

[13]. Sreejith CC, Hrridasan N, Muraleedharan C, Arun P. Allothermal air-steam gasification of biomass with $\mathrm{CO}_{2}$ (carbon dioxide) sorption: Performance prediction based on a chemical kinetic model. Energy 2014; 69: 399-408. 
[14]. Roberts DG. Harris DJ. Char gasification in mixtures of $\mathrm{CO}_{2}$ and $\mathrm{H}_{2} \mathrm{O}$ : Competition and inhibition. Fuel 2007; 86(17-18): 2672-2678.

[15]. Scala F. Fluidized bed gasification of lignite char with $\mathrm{CO}_{2}$ and $\mathrm{H}_{2} \mathrm{O}$ : A kinetic study. Proceedings of the combustion institute 2015; 35(3): 2839-2846.

[16]. Wang YL, Zhu SH, Gao MQ, Yang ZR, Yan LJ, Bai YH, Li F. A study of char gasification in $\mathrm{H}_{2} \mathrm{O}$ and $\mathrm{CO}_{2}$ mixtures: Role of inherent minerals in the coal. Fuel Processing Technology 2015; In Press, Corrected Proof.

[17]. Chen C, Wang J, Liu W, Zhang S, Yin JS, Luo GQ, Yao H. Effect of pyrolysis on the char gasification with mixtures of $\mathrm{CO}_{2}$ and $\mathrm{H}_{2} \mathrm{O}$. Proceedings of the Combustion Institute 2013; 34(2): 2453-2460.

[18]. Guizani C, Escudero Sanz FJ, Salvador S. The gasification reactivity of high-heating-rate chars in single and mixed atmospheres of $\mathrm{H}_{2} \mathrm{O}$ and $\mathrm{CO}_{2}$. Fuel 2013; 108: 812-823.

[19]. Bai YH, Wang YL, Zhu SH, Yan LJ, Li F, Xie KC. Synergistic effect between $\mathrm{CO}_{2}$ and $\mathrm{H}_{2} \mathrm{O}$ on reactivity during coal chars gasification. Fuel 2014; 126: 1-7.

[20]. Moatafavi E, Mahipey N, Manovi V. A novel development of mixed catalyst-sorbent pellets for steam gasification of coal chars with in suit $\mathrm{CO}_{2}$ capture. Catalysis Today 2014; 238: 111-117.

[21]. Sedghkerdar MH, Mostafavi E, Mahinpey N. Sorbent enhanced hydrogen production from steam gasification of coal integrated with $\mathrm{CO}_{2}$ capture. International Journal of Hydrogen Energy 2014; 39: 17001-17008.

[22]. Li FH, Yan QX, Huang JJ, Zhao JT, Fang YT, Wang JF. Lignite-char gasification 
mechanism in mixed atmospheres of steam and $\mathrm{CO}_{2}$ at different pressures. Fuel Processing Technology 2015; In Press, Corrected Proof.

[23]. Zhang H, Wang H, Zhu X, Qiu YJ, Li K, Chen R, Liao Q. A review of waste heat recovery technologies towards molten slag in steel industry. Applied Energy 2013; 112: 956-966.

[24]. Sadek DM. Effect of cooling technique of blast furnace slag on the thermal behavior of solid cement bricks. Journal of Cleaner Production 2014; 79: $134-141$

[25]. Luo SY, Zhou YM, Yi CJ. Hydrogen-rich gas production from biomass catalytic gasification using hot blast furnace slag as heat carrier and catalyst in moving-bed reactor. International Journal of Hydrogen Energy 2012; 37: 15081-15085.

[26]. Luo SY, Yi CJ, Zhou YM. Bio-oil production by pyrolysis of biomass using hot blast furnace slag. Renewable Energy 2013; 50: 373-377.

[27]. Sun YQ, Zhagn ZT, Seetharaman S, Liu LL, Wang XD. Characteristics of low temperature biomass gasification and syngas release behavior using hot slag. RSC Advances 2014; 4: 62105-62114.

[28]. Sun YQ, Nakano J, Liu LL, Wang XD, Zhang ZT. Achieving waste heat to energy through sewage sludge gasification using hot slags: syngas production. Scientific Reports 2015; 5: 11436-11448.

[29]. Sun YQ, Zhang ZT, Liu LL, Wang XD. Integrated carbon dioxide/sludge gasification using waste heat from hot slags: Syngas production and sulfur dioxide fixation. Bioresource Technology 2015; 181: 174-182. 
[30]. Li P, Yu QB, Qin Q, Liu JX. Adaptability of coal gasification in molten blast furnace slag on coal samples and granularities. Energy \& Fuels 2011; 25(12): $5678-5682$.

[31]. Li P, Yu QB, Qin Q, Lei W. Kinetics of $\mathrm{CO}_{2}$ coal gasification in molten blast furnace slag. Industrial \& Engineering Chemistry Research 2012; 51(49): $15872-15783$

[32]. Liu JX, Yu QB, Li P, Du WY. Cold experiments on ligament formation for blast furnace slag granulation. Applied Thermal Engineering 2012; 40: 351-357.

[33]. Li P, Yu QB, Xie HQ, Qin Q, Wang K. $\mathrm{CO}_{2}$ gasification rate analysis of Datong coal using slag granules as heat carrier for heat recovery from blast furnace slag by using a chemical reaction. Energy \& Fuels 2013; 27(8): 4810-4817.

[34]. Li P, Yu QB, Qin Q, Du W. The effects of slag compositions on the coal gasification reaction in molten blast furnace slag. Energy Sources, Part A 2014; 36: 73-79.

[35]. Li P, Lei W, Wu B, Yu QB. $\mathrm{CO}_{2}$ gasification rate analysis of coal in molten blast furnace slag-For heat recovery from molten slag by using a chemical reaction. International Journal of Hydrogen Energy 2015; 40: 1607-1615.

[36]. Duan WJ, Yu QB, Xie HQ, Qin Q, Zuo ZL. Thermodynamic analysis of hydrogen-rich gas generation from coal/steam gasification using blast furnace slag as heat carrier. International Journal of Hydrogen Energy 2014; 39: 11611-11619.

[37]. Duan WJ, Yu QB, Zuo ZL, Qin Q, Li P, Liu JX. The technological calculation 
for synergistic system of BF slag waste heat recovery and carbon resources reduction. Energy Conversion and Management 2014; 87: 185-190.

[38]. Duan WJ, Yu QB, Wang K, Qin Q, Hou LM, Yao X, Wu TW. ASPEN Plus simulation of coal integrated gasification combined blast furnace slag waste heat recovery system. Energy Conversion and Management 2015; 100: 30-36.

[39]. Duan WJ, Yu QB, Lei W, Chen W, Yu QB, Wang K, Qin Q. Thermodynamic analysis of blast furnace slag waste heat-recovery system integrated with coal gasification. JOM 2015; 67: 1079-1085.

[40]. Aline Lima da Silva, Iduvirges Lourdes Müller. Operation of solid oxide fuel cells on glycerol fuel: A thermodynamic analysis using the Gibbs free energy minimization approach. Journal of Power Sources 2010; 195(17): 5637-5644.

[41]. Shabbar S, Janajreh I. Thermodynamic equilibrium analysis of coal gasification using Gibbs energy minimization method. Energy Conversion and Management 2013; 65: 755-763.

[42]. Jarungthammachote S, Dutta A. Equilibrium modeling of gasification: Gibbs free energy minimization approach and its application to spouted bed and spout-fluid bed gasifiers. Energy Conversion and Management 2008; 49: $1345-1356$.

[43]. Fournel S, Marcos B, Godbout S, Heitz M. Predicting gaseous emissions from small-scale combustion of agricultural biomass fuels. Bioresource Technology 2015; 179: 165-172.

[44]. Koukkari P, Pajarre R. Introducing mechanistic kinetics to the Lagrangian Gibbs 
energy calculation. Computers and Chemical Engineering 2006; 30(6-7): 1189-1196.

[45]. McBride BJ, Gordon S, Reno MA. Coefficients for calculating thermodynamic and transport properties of individual species. NASA Technical Memorandum 4513, NASA; 1993.

[46]. Anapagaddi R, Thiruvengadam R, Subramaniam P, Voolapalli RK, Cho YS, Renganathan T. Generalized analysis of gasifier performance using equilibrium modeling. Industrial \& Engineering Chemistry Research 2012; 51: 1601-1611.

[47]. Li X, Grace JR, Watkinson AP, Lim CJ, Ergüdenler A. Equilibrium modeling of gasification: a free energy minimization approach and its application to a circulating fluidized bed coal gasifier. Fuel 2001; 80(2): 195-207.

[48]. Özkara-Aydınoglu S. Thermodynamic equilibrium analysis of combined carbon dioxide reforming with steam reforming of methane to synthesis gas. International Journal of Hydrogen Energy 2010; 35: 12821-12828.

[49]. Antzara A, Heracleous E, Bykur DB, Lemonidou AA. Thermodynamic analysis of hydrogen production via chemical looping steam methane reforming coupled with in situ $\mathrm{CO}_{2}$ capture. International Journal of Greenhouse Gas Control 2015; 32: $115-128$.

[50]. Nagaoka K, Takanabe K, Aika K. Influence of the reduction temperature on catalytic activity of $\mathrm{Co} / \mathrm{TiO}_{2}$ (anatase-type) for high pressure dry reforming of methane. Applied Catalysis A: General 2003; 255: 13-21.

[51]. Nagaoka K, Okamura M, Aika K. Titania supported ruthenium as a 
cokin-resistant catalyst for high pressure dry reforming of methane. Catalyst Communication 2001; 2: 255-260.

[52]. Jayaraman K, Gokalp I. Effect of char gasification method on steam, $\mathrm{CO}_{2}$ and blended mixture gasification of high ash Turkish coal. Fuel 2015; 153: 320-327.

[53]. Zamboni I, Zimmermann Y, Kiennemann A, Courson C. Improvement of steam reforming of toluene by $\mathrm{CO}_{2}$ capture using $\mathrm{Fe} / \mathrm{CaO}-\mathrm{Ca}_{12} \mathrm{Al}_{14} \mathrm{O}_{33}$ bi-functional materials. International Journal of Hydrogen Energy 2015, 40: 5297-5304.

[54]. Corbetta M, Manenti F, Soares F, Ravaghi-Ardebili Z, Eliseo R, Pirola C, Buzzi-Ferraris G, Pierucci S. Mathematical modeling of coal and biomass gasification comparison on the syngas $\mathrm{H}_{2} / \mathrm{CO}$ ratio under different operating conditions. Computer Aided Chemical Engineering 2014; 33: 1669-1674.

[55]. Choudhary VR, Mondal KC. $\mathrm{CO}_{2}$ reforming of methane combined with steam reforming or partial oxidation of methane to syngas over $\mathrm{NdCoO}_{3}$ perovskite-type mixed metal-oxide catalyst. Applied Energy 2006; 83: 1024-1032.

[56]. Iwarere S, Rohani V, Ramjugernath D, Fabry F, Fulcheri L. Hydrocarbon synthesis from syngas by very pressure plasma. Chemical Engineering Journal $2014 ; 241: 1-8$.

[57]. Zhang Q, Fan FY, Xu GM, Ye DJ, Wang WH, Zhu ZB. Steam reforming of dimethyl ether over a novel anodic $\gamma-\mathrm{Al}_{2} \mathrm{O}_{3}$ supported copper bi-function catalyst. International Journal of Hydrogen Energy 2013; 38(25): 10305-10314.

[58]. Remón J, Mercado V, García L, Arauzo J. Effect of acetic acid, methanol and potassium hydroxide on the catalytic steam reforming of glycerol: 
Thermodynamic and experimental study. Fuel Process Technology 2015; 138: $325-336$

[59]. Sun Y, Ritchie T, Hla SS, Mcevoy S, Stein W, Edwards JH. Thermodynamic analysis of mixed and dry reforming of methane for solar thermal applications. Journal of Natural Gas Chemistry 2011; 20: 568-576.

[60]. Essmaili P, Dincer I, Naterer GF. Development and analysis of an integrated photovoltaic system for hydrogen and methanol production. International Journal of Hydrogen Energy 2015; 40(34): 11140-11153.

[61]. Kopyscinski J, Schildhauer TJ, Biollaz SMA. Production of synthetic natural gas (SNG) from coal and dry biomass-a technology review from 1950 to 2009. Fuel 2010; 89: 1763-1783.

[62]. Wang ZH, Zhou JH, Wang QH, Fan JR, Cen KF. Thermodynamic equilibrium analysis of hydrogen production by coal based on $\mathrm{Coal} / \mathrm{CaO} / \mathrm{H}_{2} \mathrm{O}$ gasification system. International Journal of Hydrogen Energy 2006; 31: 945-952.

[63]. Doyle TS, Dehouche Z, Araving PV, Liu M, Stankovic S. Investigating the impact and reaction pathway of toluene on a SOFC running on syngas. International Journal of Hydrogen Energy 2014; 39(23): 12083-12091.

[64]. Chutichai B, Authayanun S, Assbumrungrat S, Arpornwichanop A. Performance analysis of an integrated biomass gasification and PEMFC (proton exchange membrane fuel cell) system: Hydrogen and power generation. Energy 2013; 55: 96-106. 


\section{TABLE CAPTION}

Table 1 The properties of DT bituminous coal

Table 2 The list of BFS solid phase species 


\section{FIGURE CAPTION}

Fig. 1 Effect of pressure on the equilibrium of the Carbon, $\mathrm{CO}_{2}$ conversions and $\mathrm{H}_{2}$, $\mathrm{CO}$ yield for the coal/ $\mathrm{CO}_{2}$ gasification reaction at $800{ }^{\circ} \mathrm{C}$

Fig. 2 Effect of steam addition on the equilibrium of the Carbon, $\mathrm{CO}_{2}$ and $\mathrm{H}_{2} \mathrm{O}$ conversions for the combined $\mathrm{C} / \mathrm{CO}_{2} / \mathrm{H}_{2} \mathrm{O}$ gasification reaction at different temperatures with $\mathrm{C} / \mathrm{CO}_{2}=1.0$ and atmospheric pressure

Fig. 3 Effect of steam addition on the equilibrium of the $\mathrm{H}_{2}$ yield (\%), and $\mathrm{CO}$ yield (\%) for the combined $\mathrm{C} / \mathrm{CO}_{2} / \mathrm{H}_{2} \mathrm{O}$ gasification reaction at different temperatures with $\mathrm{C} / \mathrm{CO}_{2}=1.0$ and atmospheric pressure

Fig. 4 The equilibrium of the (a) Carbon conversion (\%), (b) $\mathrm{CO}_{2}$ conversion (\%) and (c) $\mathrm{H}_{2} \mathrm{O}$ conversion (\%) for the combined $\mathrm{C} / \mathrm{CO}_{2} / \mathrm{H}_{2} \mathrm{O}$ gasification reaction for various $\mathrm{CO}_{2} / \mathrm{C}$ and $\mathrm{H}_{2} \mathrm{O} / \mathrm{C}$ at different temperatures and atmospheric pressure

Fig. 5 The equilibrium of the (a) $\mathrm{H}_{2}$ yield (\%), and (b) $\mathrm{CO}$ yield (\%) for the combined $\mathrm{C} / \mathrm{CO}_{2} / \mathrm{H}_{2} \mathrm{O}$ gasification reaction for various $\mathrm{CO}_{2} / \mathrm{C}$ and $\mathrm{H}_{2} \mathrm{O} / \mathrm{C}$ at different temperatures and atmospheric pressure

Fig. 6 The equilibrium of the $\mathrm{H}_{2} / \mathrm{CO}$ ratio for the combined $\mathrm{C} / \mathrm{CO}_{2} / \mathrm{H}_{2} \mathrm{O}$ gasification reaction for various $\mathrm{CO}_{2} / \mathrm{C}$ and $\mathrm{H}_{2} \mathrm{O} / \mathrm{C}$ at $800{ }^{\circ} \mathrm{C}$ and atmospheric pressure Fig. 7 The LHV of the production syngas for the combined $\mathrm{C} / \mathrm{CO}_{2} / \mathrm{H}_{2} \mathrm{O}$ gasification reaction for various $\mathrm{CO}_{2} / \mathrm{C}$ and $\mathrm{H}_{2} \mathrm{O} / \mathrm{C}$ at $800{ }^{\circ} \mathrm{C}$ and atmospheric pressure 